\title{
A construção do conhecimento e o aprisionamento pelos seus referenciais
}

\author{
Autor: Jorge W. F. Amaro \\ São Paulo: Casa Leitura Médica; 2010
}

\section{ZACARIa Borge Ali RAMAdam ${ }^{1}$}

† Professor-associado do Departamento de Psiquiatria da Faculdade de Medicina da Universidade de São Paulo (FMUSP).

Recebido: 23/1/2012 - Aceito: 13/2/2012

Ramadam ZBA / Rev Psiq Clín. 2012;39(3):113-4

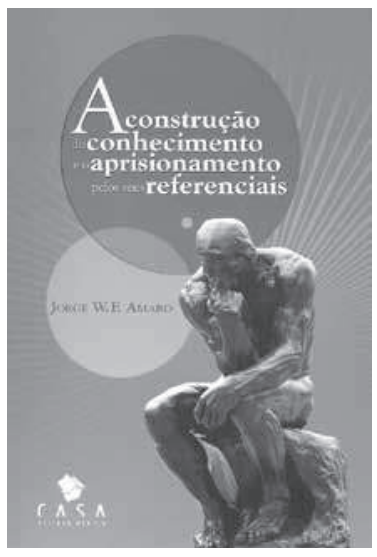

Desde Newton e Galileu, o cálculo e a matemática robusteceram seu prestígio no universo científico e acadêmico.

Mesmo estudiosos de fenômenos fisicamente não mensuráveis renderam-se ao fascínio dos números, recorrendo à estatística como se fosse garantia de verdades indiscutíveis.

É possível medir a consciência? A tristeza? O prazer?

Quantos ovos podem-se consumir sem elevar a taxa de colesterol?

Quando as estatísticas são divergentes, recorre-se à metanálise, ou seja, a análise estatística das pesquisas baseadas em estatísticas.

Há um século, Karl Jaspers, pai da psicopatologia moderna, advertia que "com números pode-se provar tudo"; os mais irônicos definem a estatística como "a arte de torturar os números".

Não obstante, essa mística não é totalmente imerecida: os números propiciaram viagens espaciais, internet, celulares e múltiplas outras comodidades tecnológicas - até foguetes e bombas atômicas. Terremotos e tsunamis, porém, ainda continuam imprevisíveis.

As guerras e outras mazelas humanas continuam sendo objeto da arte e da literatura.

O amplo espectro de interesses da pesquisa levou Abraham Moles a criar o conceito de "ciências do impreciso", a exemplo da meteorologia, baseada também nas estatísticas e na incerteza, postulada por Heisenberg no campo da física quântica. Nesse quadro transitório e precário, em que, muitas vezes, os erros ensinam mais que os acertos, cientistas bem-humorados criaram o "prêmio Ig-Nobel" para homenagear pesquisas bizarras e inúteis.

Hoje, dezenas de milhares de revistas científicas são publicadas em todo o mundo; na área de Medicina e Psiquiatria, o número é incalculável.

Entretanto, para compreender um artigo é mais importante dominar conhecimentos de estatística do que a matéria tratada no texto.

Algumas décadas atrás, livros médicos limitavam-se a citar casos ilustrativos e percentuais de incidência das patologias; e, no entanto, as linhas mestras da medicina moderna foram assim estabelecidas, sem a sofisticação e as variáveis estatísticas.

Todas essas questões evidenciam uma crise no âmbito das ciências e na busca do conhecimento. E é disso que trata o livro do prof. Amaro, nos seus 10 substanciais capítulos.

No primeiro - "A construção do conhecimento nas relações humanas" -, por meio da psicologia e da psicanálise, o autor mostra a importância dos aspectos psíquicos emocionais nos relacionamentos e sua interferência no plano cognitivo e da memória, bem como as pressões da fantasia e do desejo na elaboração do conhecimento, com riqueza de informações, sustentadas por 42 referências bibliográficas; segue-se o capítulo sobre personalidade, temperamento e caráter e as influências culturais correspondentes, numa impecável exposição didática. Discorre, a seguir, sobre as relações compreensivas da vida psíquica e a construção do conhecimento, com ênfase na psicopatologia.

Segue-se, a partir do quarto capítulo, a discussão sobre as concepções interdisciplinares, remontando-se aos mitos bíblicos da criação do universo, passando por Ptolomeu, Copérnico, Edwin Huble, Einstein, Hawking e o "Big-Bang".

Nos capítulos subsequentes, discute a diversidade e a unidade na construção do conhecimento, discorrendo sobre os aspectos mitológicos, filosóficos e psicológicos nesse processo, formulando com segurança um debate entre as ideias de Platão, Descartes, Kant, Hegel e Comte. Marx, Engels e Schopenhauer também participam do debate, além de Sartre e Heidegger.

Nos capítulos 8 e 9, são discutidos, com apoio em vasta e atualizada bibliografia, os fundamentos da matemática, da física e da astronomia, com profundidade e erudição incomuns no âmbito das publicações nacionais.

Seguem-se as considerações finais, que reservamos à curiosidade dos leitores. 
Formado em medicina, Jorge W. F. Amaro é psiquiatra e psicanalista, com décadas de experiência com os mais íntimos e complexos problemas humanos; livre-docente e professor-associado do Departamento de Psiquiatria da Faculdade de Medicina da Universidade de São Paulo, com marcante participação em congressos científicos nacionais e internacionais, é autor de vários livros e numerosos artigos científicos.

Sua obra revela uma ampla e insaciável curiosidade científica, aliada a uma inteligência privilegiada, que o fizeram credor do respeito e admiração de seus alunos e colegas da Universidade de São Paulo.
O livro contempla um espectro abrangente de disciplinas científicas e seus referenciais, como um aguilhão no cerne de todos os dogmatismos; mas é, contudo, um entusiasmado convite à busca do conhecimento e da verdade, mesmo que transitórios.

Trata-se de uma obra ímpar na literatura nacional contemporânea, indicada para todos que refletem sobre os descaminhos e vicissitudes da construção do conhecimento. 